\title{
PEMETAAN RISIKO PENCEMARAN AIRTANAH DI KECAMATAN PIYUNGAN, KABUPATEN BANTUL MENGGUNAKAN METODE DRASTIC MODIFIKASI
}

\author{
Fedhi Astuty Hartoyo ${ }^{1}$, Ahmad Cahyadi², Gilang Arya Dipayana ${ }^{2}$ \\ ${ }^{1}$ Mahasiwa Kartografi dan Pengideraan Jauh, Fakultas Geografi, Universitas Gadjah Mada \\ ${ }^{2}$ Program BEASISWA UNGGULAN Biro Perencanaan dan Kerjasama Luar Negeri (BPKLN) \\ Kementrian Pendidikan Nasional Republik Indonesia pada Magister Perencanaan Pengelolaan Pesisir \\ dan Daerah Aliran Sungai, Fakultas Geografi, Universitas Gadjah Mada, Yogyakarta \\ Email: fed.hartoyo@gmail.com, ahmadcahyadi@geo.ugm.ac.id
}

\begin{abstract}
ABSTRAK
Perkembangan wilayah Perkotaan Yogyakarta telah menyebabkan pertambahan penduduk dan perubahan penggunaan/ penutup lahan dari lahan non-terbangun menjadi lahan terbangun di wilayah sekitarnya, diantaranya adalah Kecamatan Piyungan. Hal tersebut akan menyebabkan semakin banyaknya kebutuhan akan air serta meningkatkan risiko pencemaran air termasuk airtanah. Penelitian ini bertujuan untuk (1) mengetahui sebaran spasial kerentanan airtanah di Kecamatan Piyungan, Kabupaten Bantul, dan (2) sebaran spasial risiko pencemaran airtanah di Kecamatan Piyungan, Kabupaten Bantul.

Pemetaan kerentanan airtanah dilakukan dengan menggunakan Metode DRASTIC dengan analisis overlay menggunakan sistem informasi geografis (SIG). Data yang digunakan dalam Metode DRASTIC meliputi peta kedalaman airtanah, peta curah hujan wilayah, peta media akuifer, peta tekstur tanah, peta kemiringan lereng, peta media akuifer tidak jenuh dan peta konduktivitas hidraulik. Risiko pencemaran airtanah dihasilkan dari overlay peta penggunaan lahan sebagai gambaran bahaya pencemaran dan peta kerentanan airtanah yang dihasilkan dari tujuan pertama. Hasil penelitian ini adalah (1) kerentanan airtanah di Kecamatan Piyungan terdiri atas tingkat tidak rentan sampai dengan kerentanan airtanah sangat tinggi. Wilayah yang tergolong tidak rentan adalah wilayah bukan akuifer yang menempati perbukitan dengan batuan vulkanik tersier yang kedap air, sedangkan kerentanan sangat tinggi terdapat pada dataran aluvial Merapi bagian Timur Laut Kecamatan Piyungan. (2) risiko pencemaran airtanah di Kecamatan Piyungan terdiri atas tingkat risiko sangat rendah sampai dengan risiko tinggi, di mana risiko tinggi terdapat pada dataran aluvial Merapi yang terletak di bagian Timur Laut.
\end{abstract}

Kata Kunci: Kerentanan Airtanah, Risiko Pencemaran Airtanah, DRASTIC Modifikasi, Overlay, Sistem Informasi Geografis (SIG)

\section{PENDAhUluAN}

\subsection{Latar Belakang}

Pertambahan penduduk dan perubahan penggunaan/ penutup lahan dari non-terbangun menjadi lahan terbangun merupakan indikator adanya suatu perkembangan wilayah perkotaan, termasuk Yogyakarta. Wilayah Kota Yogyakarta mengalami perembetan sifat kekotaan dominan ke arah utara dan arah barat, meskipun demikian kecenderungan perubahan penggunaan lahan pada bagian timur (jalur Yogyakarta-Gunungkidul) di Kecamatan Piyungan juga mengalami perkembangan yang cukup pesat. Perubahan penutup/ penggunaan lahan yang semakin meluas ini akan berdampak pada adanya penurunan kualitas lingkungan, termasuk penurunan kualitas air.

Airtanah merupakan salah satu sumberdaya air yang mempunyai potensi dalam pemenuhan kebutuhan air. Sudarmadji (1990) menyebutkan bahwa keuntungan dari airtanah adalah mempunyai kualitas yang relatif baik dibanding air permukaan dan tidak terpengaruh musim, cadangan airtanah 
lebih besar dan lebih mudah diperoleh dengan cara yang sederhana, dan mempunyai biaya yang murah. Vörösmarty et al. (2000) menunjukan bahwa masalah air terjadi karena adanya peningkatan penduduk bumi dan perubahan penutup/ penggunaan lahan sebagai akibat dari pertumbuhan penduduk yang menuntut penyediaan lahan guna mendukung berbagai aktivitasnya.

Permasalahan air dapat terjadi karena adanya penurunan kualitas air akibat pencemaran. Comans, dkk (1987) menyampaikan bahwa antara kualitas airtanah dan penggunaan lahan di atasnya terdapat korelasi. Perubahan penggunaan lahan akan memberikan pengaruh pada penutup lahan yang sifatnya memberikan keseimbangan ekologis. Oleh karena itu, penelitian mengenai pemetaan risiko airtanah perlu dilakukan guna mendukung perencanaan pengelolaan lingkungan, khususnya airtanah.

\subsection{Tujuan Penelitian}

Tujuan penelitian ini adalah untuk 1) mengetahui sebaran spasial kerentanan airtanah di Kecamatan Piyungan, Kabupaten Bantul, dan (2) sebaran spasial risiko pencemaran airtanah di Kecamatan Piyungan, Kabupaten Bantul.

\section{STUDI AREA}

Studi area terletak di Kecamatan Piyungan, Kabupaten Bantul, Propinsi Daerah Istimewa Yogyakarta.

\section{DATA DAN METODE}

Parameter Penentu, Data, dan Sumber Data yang digunakan dalam penelitian ini dapat dilihat pada Tabel 3.1.

Tabel 3.1 Tabel Parameter Penentu, Data, dan Sumber Data

\begin{tabular}{|c|c|c|c|c|}
\hline Bagian & Parameter Penentu & Data & Metode & Sumberdata \\
\hline \multirow{9}{*}{ 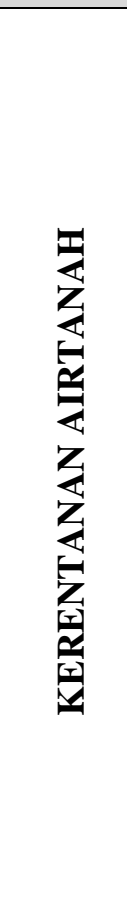 } & \multirow{3}{*}{$\begin{array}{l}\text { Kedalaman Muka } \\
\text { Airtanah (D) }\end{array}$} & $\begin{array}{l}\text { Ploting Lokasi } \\
\text { Sumur }\end{array}$ & Ploting GPS (Pengukuran Lapangan) & $\begin{array}{l}\text { Pengukuran } \\
\text { Lapangan }\end{array}$ \\
\hline & & $\begin{array}{l}\text { Kedalaman Muka } \\
\text { Airtanah }\end{array}$ & Pengukuran Kedalaman Sumur & $\begin{array}{l}\text { Pengukuran } \\
\text { Lapangan }\end{array}$ \\
\hline & & $\begin{array}{l}\text { Peta Kedalaman } \\
\text { Muka Airtanah }\end{array}$ & $\begin{array}{l}\text { Interpolasi Spline Method pada ArcGIS } \\
\text { 9.x }\end{array}$ & $\begin{array}{l}\text { Titik Lokasi } \\
\text { Sumur }\end{array}$ \\
\hline & \multirow{3}{*}{$\begin{array}{l}\text { Curah Hujan Wilayah } \\
\text { (R) }\end{array}$} & $\begin{array}{l}\text { Lokasi Stasiun } \\
\text { Hujan }\end{array}$ & $\begin{array}{l}\text { Pengumpulan Data Hujan Tahun 1971- } \\
2009\end{array}$ & $\begin{array}{l}\text { BMKG DIY dan } \\
\text { BPDAS Opak Oya }\end{array}$ \\
\hline & & $\begin{array}{l}\text { Curah Hujan } \\
\text { Tahunan }\end{array}$ & $\begin{array}{l}\text { Pengolahan Data Hujan (Pengisian Data } \\
\text { Hujan, Uji Konstensi, dan Uji Korelasi) }\end{array}$ & - \\
\hline & & $\begin{array}{l}\text { Peta Curah Hujan } \\
\text { Wilayah }\end{array}$ & $\begin{array}{l}\text { Isohyet Method dengan Interpolasi } \\
\text { Kriging Method pada ArcGIS 9.x }\end{array}$ & - \\
\hline & \multirow{3}{*}{ Media Akuifer (A) } & Data Bor & Pengumpulan Data Sekunder & Dinas P2TK \\
\hline & & $\begin{array}{l}\text { Kecamatan } \\
\text { Piyungan }\end{array}$ & $\begin{array}{l}\text { Pengukuran dengan Geolistrik } \\
\text { Schlumberger Method }\end{array}$ & $\begin{array}{l}\text { Pengukuran } \\
\text { Lapangan }\end{array}$ \\
\hline & & $\begin{array}{l}\text { Peta Media } \\
\text { Akuifer }\end{array}$ & Interpolasi Data Bor dan Geolistrik & - \\
\hline
\end{tabular}




\begin{tabular}{|c|c|c|c|c|}
\hline & Tekstur Tanah (S) & $\begin{array}{l}\text { Peta Tanah } \\
\text { Kecamatan } \\
\text { Piyungan }\end{array}$ & $\begin{array}{l}\text { Ekstraksi dari Peta Tanah Semi Detil } \\
\text { Skala 1:50000 }\end{array}$ & $\begin{array}{l}\text { PUSLITANAK } \\
\text { Tahun } 1994\end{array}$ \\
\hline & & & $\begin{array}{l}\text { Ekstraksi dari Peta Rupa Bumi Indonesia } \\
\text { Skala 1:25000 }\end{array}$ & $\begin{array}{l}\text { Peta RBI 1:25000 } \\
\text { Bakosurtanal }\end{array}$ \\
\hline & Kemiringan Lereng & $\begin{array}{l}\text { Peta Kontur } \\
\text { Kecamatan }\end{array}$ & $\begin{array}{l}\text { Pembuatan Model DEM (Digital } \\
\text { Elevation Model) pada ArcGIS 9.x }\end{array}$ & - \\
\hline & & Piyungan & $\begin{array}{l}\text { Pembuatan Peta Lereng dengan } 3 D \\
\text { Analyst }>\text { Surface Analyst }>\text { Slope pada } \\
\text { ArcGIS 9.x }\end{array}$ & - \\
\hline & & Data Bor & Pengumpulan Data Sekunder & Dinas P2TK \\
\hline & Zona Tidak Jenuh (I) & $\begin{array}{l}\text { Kecamatan } \\
\text { Piyungan }\end{array}$ & $\begin{array}{l}\text { Pengukuran dengan Geolistrik } \\
\text { Schlumberger Method }\end{array}$ & - \\
\hline & & $\begin{array}{l}\text { Peta Zona Tak } \\
\text { Jenuh }\end{array}$ & Interpolasi Data Bor dan Geolistrik & - \\
\hline & & Data Bor & Pengumpulan Data Sekunder & Dinas P2TK \\
\hline & Konduktivitas & $\begin{array}{l}\text { Kecamatan } \\
\text { Piyungan }\end{array}$ & $\begin{array}{l}\text { Pengukuran dengan Geolistrik } \\
\text { Schlumberger Method }\end{array}$ & - \\
\hline & Hidraulik ( C) & $\begin{array}{l}\text { Nilai } \\
\text { Konduktivitas }\end{array}$ & $\begin{array}{l}\text { Pendekatan Nilai Material Akuifer } \\
\text { dengan Nilai Konduktivitas Hidraulik }\end{array}$ & - \\
\hline & & Hidraulik & Interpolasi Nilia $\mathrm{C}$ & - \\
\hline & Kerentanan Airtanah & $\begin{array}{l}\text { Nila Parameter } \\
\text { Penentu }\end{array}$ & $\begin{array}{l}\text { Weighted Overlay Index pada ArcGIS } \\
\text { 9.x }\end{array}$ & $\begin{array}{l}\text { Hasil Perhitungan } \\
\text { Parameter Penentu }\end{array}$ \\
\hline Dicilz & Pena & $\begin{array}{l}\text { Peta Penggunaan } \\
\text { Lahan }\end{array}$ & $\begin{array}{l}\text { Ekstraksi dari Peta Rupa Bumi Indonesia } \\
\text { Skala 1:25000 }\end{array}$ & $\begin{array}{l}\text { Peta RBI 1:25000 } \\
\text { Bakosurtanal }\end{array}$ \\
\hline RISIKo & Penggunaan Lanan & $\begin{array}{l}\text { Peta Lokasi } \\
\text { Industri }\end{array}$ & Ekstraksi dari Peta Lokasi Industri & $\begin{array}{l}\text { Dinas } \\
\text { Perindustrian }\end{array}$ \\
\hline
\end{tabular}

Metode yang digunakan dalam penelitian ini adalah metode DRASTIC, di mana merupakan singkatan dari parameter-parameter yang digunakan dalam metode ini (lihat Gambar 3.1). Analisis dilakukan dengan memberikan bobot pada masing-masing parameter dan memberikan skor pada setiap klasifikasi dalam parameter yang digunakan. Klasifikasi pada tiap-tiap parameter di metode pemetaan kerentanan airtanah dengan DRASTIC dapat dilihat pada tabel-tabel berikut ini Widyastuti, dkk (2006):

Tabel 3.2.Nilai Parameter Kedalaman Airtanah yang Digunakan Dalam Metode DRASTIC

\begin{tabular}{|c|c|c|}
\hline No. & Kedalaman Muka Airtanah (meter) & Nilai \\
\hline 1. & $0-1,5$ & 10 \\
\hline 2. & $>1,5-3$ & 9 \\
\hline 3. & $>3-9$ & 7 \\
\hline 4. & $>9-15$ & 5 \\
\hline 5. & $>15-22$ & 3 \\
\hline 6. & $>22-30$ & 2 \\
\hline 7. & $>30$ & 1 \\
\hline
\end{tabular}


Tabel 3.3.Nilai Parameter Curah Hujan yang Digunakan Dalam Metode DRASTIC

\begin{tabular}{|c|c|c|}
\hline No. & Curah Hujan (mm/tahun) & Nilai \\
\hline 1. & $0-1.500$ & 2 \\
\hline 2. & $>1.500-2.000$ & 4 \\
\hline 3. & $>2.000-2.500$ & 6 \\
\hline 4. & $>2.500-3.000$ & 8 \\
\hline 5. & $>3.000$ & 10 \\
\hline
\end{tabular}

Tabel 3.4.Nilai Parameter Media Akuifer yang Digunakan Dalam Metode DRASTIC

\begin{tabular}{|c|l|c|}
\hline No. & \multicolumn{1}{|c|}{ Media Akuifer } & Nilai \\
\hline 1. & Shale Masif & 2 \\
\hline 2. & Batuan Metamorf/Beku & 3 \\
\hline 3. & Batuan Metamorf/BekuLapuk & 4 \\
\hline 4. & Batu Pasir Tipis, Shale, Batugamping & 6 \\
\hline 5. & Batu PasirMasif & 6 \\
\hline 6. & Batu Gamping Masif & 6 \\
\hline 7. & Pasir dan Kerikil & 8 \\
\hline 8. & Basalt & 9 \\
\hline 9. & Batu gamping Karst & 10 \\
\hline
\end{tabular}

Tabel 3.5.Nilai Tekstur Tanah yang Digunakan Dalam Metode DRASTIC

\begin{tabular}{|c|l|c|}
\hline No. & \multicolumn{1}{|c|}{ Tekstur Tanah } & Nilai \\
\hline 1. & Tanah Tipis & 10 \\
\hline 2. & Kerikil & 10 \\
\hline 3. & Pasir & 9 \\
\hline 4. & Shrinking dan atau Agregat Lempung & 7 \\
\hline 5. & Geluh Pasiran (Sandy Loam) & 6 \\
\hline 6. & Geluh (Loam) & 5 \\
\hline 7. & Geluh Lanauan (Silty Loam) & 4 \\
\hline 8. & Geluh Lempungan (Clay Loam) & 3 \\
\hline 9. & Non Shrinking dan non AgregatLempung & 1 \\
\hline
\end{tabular}

Tabel 3.6.Nilai Kemiringan Lereng yang Digunakan Dalam Metode DRASTIC

\begin{tabular}{|c|c|c|}
\hline No. & Kemiringan Lereng (\%) & Nilai \\
\hline 1. & $0-2$ & 10 \\
\hline 2. & $>2-6$ & 9 \\
\hline 3. & $>6-12$ & 5 \\
\hline 4. & $>12-18$ & 3 \\
\hline 5. & $>18$ & 1 \\
\hline
\end{tabular}


Tabel 3.7 Nilai Material Zona Tidak Jenuh yang Digunakan Dalam Metode DRASTIC

\begin{tabular}{|c|l|c|}
\hline No. & \multicolumn{1}{|c|}{ Material Zona Tidak Jenuh } & Nilai \\
\hline 1. & Lanau/Lempung & 1 \\
\hline 2. & Shale & 3 \\
\hline 3. & Batu Gamping & 6 \\
\hline 4. & Batu Pasir & 6 \\
\hline 5. & Batu Gamping Berlapis (Bedded Limestone) & 6 \\
\hline 6. & Shale danKerikil dengan lanau dan lanau cukup & 6 \\
\hline 7. & Pasir dan Kerikil & 4 \\
\hline 8. & Batuan Metamorf/Beku & 8 \\
\hline 9. & Basalt & 9 \\
\hline 10. & Batu Gamping Karst & 10 \\
\hline
\end{tabular}

Tabel 3.8.Nilai Konduktivitas Hidraulik yang Digunakan Dalam Metode DRASTIC

\begin{tabular}{|c|c|c|}
\hline No. & Konduktivitas Hidraulik (m/hari) & Nilai \\
\hline 1. & $0-0,86$ & 1 \\
\hline 2. & $>0,86-2,59$ & 2 \\
\hline 3. & $>2,59-6,05$ & 4 \\
\hline 4. & $>6,05-8,64$ & 6 \\
\hline 5. & $>8,64-17,18$ & 8 \\
\hline 6. & $>17,18$ & 10 \\
\hline
\end{tabular}

Parameter-parameter tersebut kemudian ditumpangsusun (overlay) sehingga menghasilkan indeks DRASTIC yang mencerminkan kerentanan airtanah. Persamaan yang digunakan dalam analisis ini adalah:

\section{Indeks DRASTIC = DwDr + RwRr + AwAr + SwSr + TwTr + IwIr + CwCr}

Keterangan :

$\mathrm{D} \quad=$ Depth to the water table (kedalaman muka airtanah);

$\mathrm{R} \quad=$ Recharge (dalam hal ini diperhitungkan sama dengan curah hujan);

$\mathrm{A} \quad=$ Aquifer media (media akuifer);

$\mathrm{S} \quad=$ Soil media (dalam analisis ini digunakan parameter tekstur tanah);

$\mathrm{T}=$ Topography (dalam analisis ini hanya digunakan parameter lereng);

I = Impact of vadose zone (pengaruh zona tidak jenuh);

$\mathrm{C} \quad=$ Conductivity (konduktuivitas hidraulik);

$\mathrm{W}=$ Bobot masing-masing parameter (nilai Bobot Lihat Gambar 3.2)

$\mathrm{r} \quad=$ nilai masing-masing parameter

Hasil tumpangsusun menggunakan sistem informasi geografis akan menghasilkan nilai indeks DRASTIC. Berikut klasifikasi kerentanan airtanah berdasarkan indeks DRASTIC: 
Tabel 3.9.Klasifikasi Kerentanan Airtanah Berdasarkan Indeks DRASTIC

\begin{tabular}{|c|c|l|}
\hline No. & Indeks DRASTIC & Klasifikasi Kerentanan Airtanah \\
\hline 1. & $73-92$ & Tidak rentan \\
\hline 2. & $>92-112$ & Kerentanan rendah \\
\hline 3. & $>112-132$ & Kerentanan sedang \\
\hline 4. & $>132-152$ & Kerentanan tinggi \\
\hline 5. & $>152-172$ & Kerentanan sangat tinggi \\
\hline
\end{tabular}

Penentuan tingkat risiko pencemaran airtanah menggunakan metode yang dilakukan oleh Widyastuti (2006) yaitu dengan melakukan tumpangsusun peta tingkat kerentanan airtanah yang merupakan hasil dari Metode DRASTIC dengan peta bahaya pencemaran airtanah yang merupakan hasil dari peta penggunaan lahan. Metode ini digunakan dengan asumsi bahwa penggunaan lahan memiliki karakteristik bahaya pencemaran yang akan berpengaruh terhadap airtanah. Penentuan nilai bahaya pencemaran airtanah dilakukan dengan menggunakan klasifikasi sebagai berikut :

Tabel 3.10 Klasifikasi Bahaya Pencemaran Masing-masing Penggunaan Lahan

\begin{tabular}{|r|l|c|}
\hline No & \multicolumn{1}{|c|}{ Tipe Penggunaan Lahan } & Nilai \\
\hline 1 & Lahan kosong/ Tidak terolah & 1 \\
\hline 2 & Hutan & 1 \\
\hline 3 & Kebun/ Perkebunan & 3 \\
\hline 4 & Tegalan & 3 \\
\hline 5 & Persawahan & 2 \\
\hline 7 & Permukiman dengan penduduk rendah; non-industri dan non-peternakan & 5 \\
\hline 8 & Permukiman dengan penduduk rendah; berindustri dan peternakan & 6 \\
\hline 9 & Permukiman dengan jumlah penduduk sedang; non-industri dan non-peternakan & 7 \\
\hline 10 & Permukiman dengan jumlah penduduk sedang; berindustri dan peternakan & 8 \\
\hline 11 & Permukiman dengan jumlah penduduk tinggi; non-industri dan non-peternakan & 9 \\
\hline 12 & Permukiman dengan jumlah penduduk tinggi; berindustri dan peternakan & 10 \\
\hline
\end{tabular}

Hasil tumpangsusun antara peta tingkat kerentanan airtanah dengan peta bahaya pencemaran airtanah menggunakan system informasi geografis, kemudian dilakukan klasifikasi sebagai berikut:

Tabel 3.11 Klasifikasi Risiko Pencemaran

\begin{tabular}{|c|c|c|}
\hline No & Indeks Kerentanan & Klasifikasi Risiko \\
\hline 1 & $81-104$ & Risiko Sangat Rendah \\
\hline 2 & $105-128$ & Risiko rendah \\
\hline 3 & $129-152$ & Risiko sedang \\
\hline 4 & $153-176$ & Risiko tinggi \\
\hline 5 & $177-200$ & Risiko sangat tinggi \\
\hline
\end{tabular}

\section{HASIL DAN PEMBAHASAN}

Berdasarkan hasil pengukuran kedalaman sumur di wilayah penelitian, diperoleh informasi bahwa kedalaman muka airtanah ialah antara 1,5 meter sampai dengan 15 meter. Airtanah yang dangkal terdapat pada dataran aluvial bagian Barat Laut dan pada kipas aluvial di dasar perbukitan. 
Airtanah tidak terdapat pada perbukitan di wilayah penelitian karena perbukitan tersebut tersusun atas batuan yang beku yang termasuk dalam satuan Formasi Nglanggran (Tmn) yang didominasi oleh batuan breksi vulkanik, sehingga air tidak dapat meresap menjadi airtanah. (lihat Gambar 4.1).

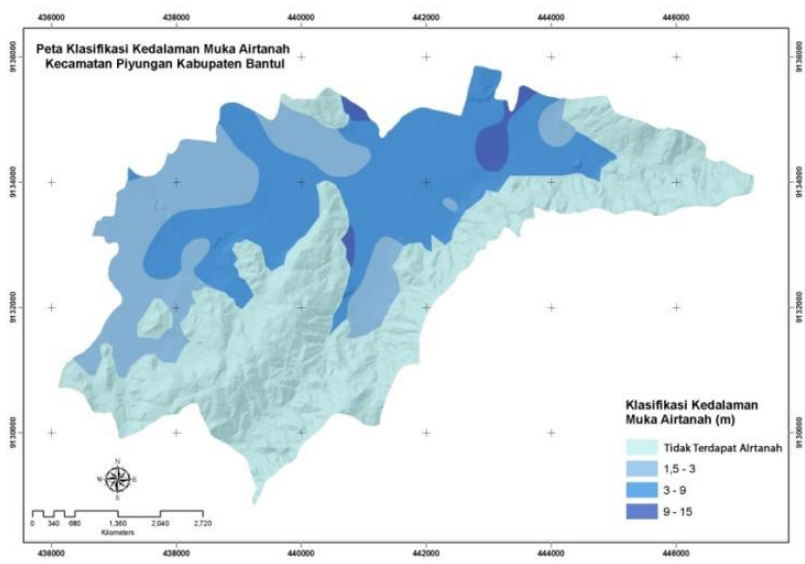

Gambar 4.1 (kiri) Peta Kedalaman Airtanah Kecamatan Piyungan

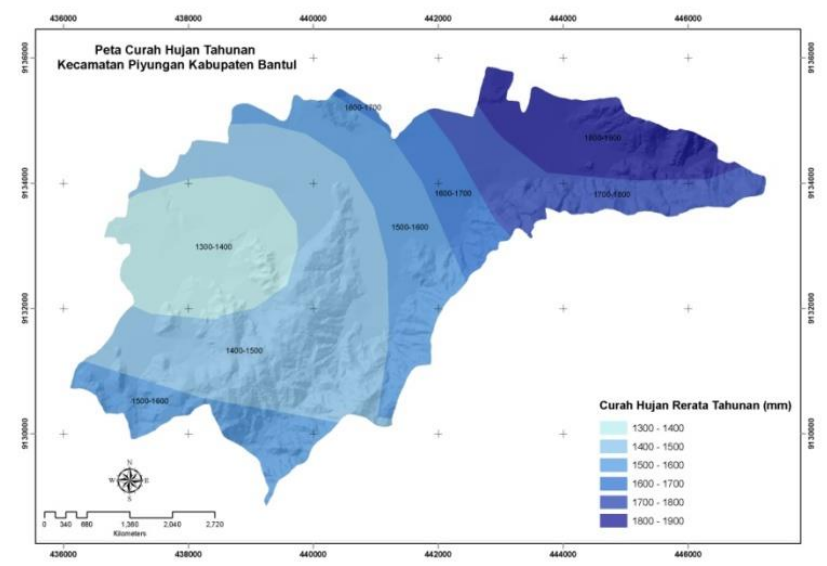

Gambar 4.2 (kanan) Peta Curah Hujan Wilayah Kecamatan Piyungan

Penentuan curah hujan dalam penelitian ini dilakukan dengan menggunakan metode isohyet, dimana data curah hujan merupakan data titik yang berasal dari data stasiun hujan dan kemudian diinterpolasi untuk mendapatkan data keruangan. Hasil penelitian menunjukkan bahwa wilayah penelitian memiliki curah hujan antara $1.300 \mathrm{~mm} /$ tahun sampai dengan $1.900 \mathrm{~mm} /$ tahun. (lihat Gambar 4.2)

Berdasarkan media akuifernya, wilayah penelitian terbagi menjadi dua wilayah, yaitu wilayah dengan akuifer berupa pasir dan kerikil, serta wilayah dengan batuan metamorf beku lapuk. Wilayah dengan akuifer berupa pasir dan kerikil merupakan bagian dari endapan aluvial Merapi, kerucut koluvial perbukitan dan kipas aluvial. Wilayah ini memiliki kerentanan pencemaran yang cukup tinggi karena material pasir dan kerikil merupakan material yang memiliki permeabilitas tinggi, sehingga filterisasi terjadi sangat sedikit (lihat Gambar 4.3)

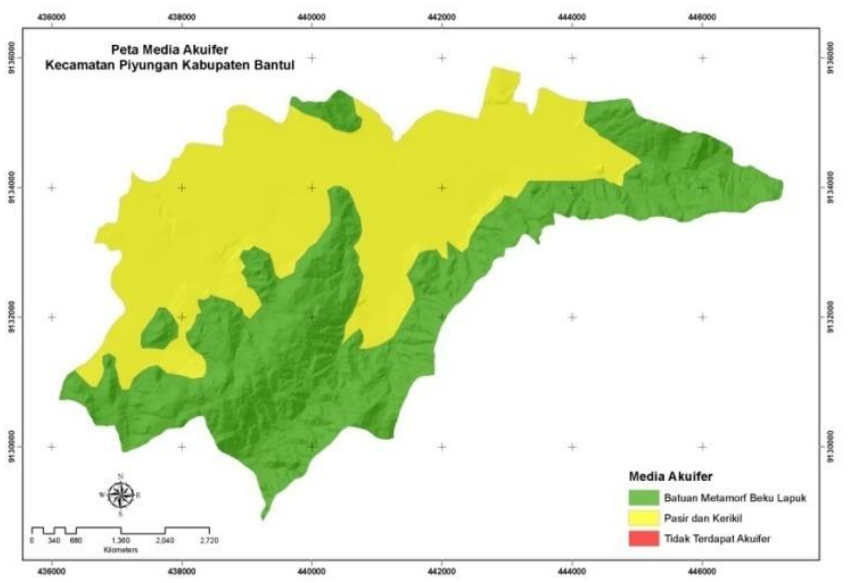

Gambar 4.3 Peta Media Akuifer

Wilayah Kecamatan Piyungan

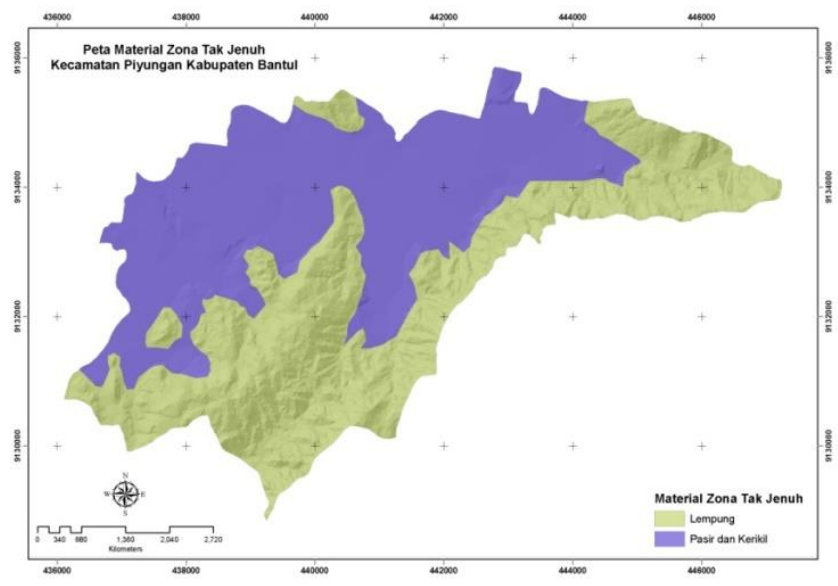

Gambar 4.4 Peta Material Zona Tak Jenuh Wilayah Kecamatan Piyungan 
Material zona tidak jenuh pada wilayah ini terbagi menjadi dua, yaitu berupa pasir dan berupa lempung. Material berupa pasir memungkinkan meresapnya bahan pencemar airtanah dengan mudah. Sedangkan wilayah yang bukan merupakan akuifer merupakan bagian dari gunungapi tersier dengan batuan kedap air dan memiliki material pada zona tidak jenuh air berupa lempung (tanah tipis pada bagian atas, banyak diantaranya merupakan singkapan batuan) (lihat Gambar 4.4).

Wilayah dengan tekstur pasir akan lebih mudah tercemar (kerentanan airtanah tinggi) dibandingkan dengan tanah bertekstur lempung (lihat Gambar 4.5). Sementara itu, peta lereng dihasilkan dari peta rupa bumi Indonesia dengan mengekstrak data kontur yang terdapat di dalam peta tersebut. Hasil analisis dengan Sistem Informasi Geografis (SIG), maka ditemukan bahwa kemiringan lereng di wilayah penelitian adalah dari datar sampai sangat curam (lihat Gambar 4.6).

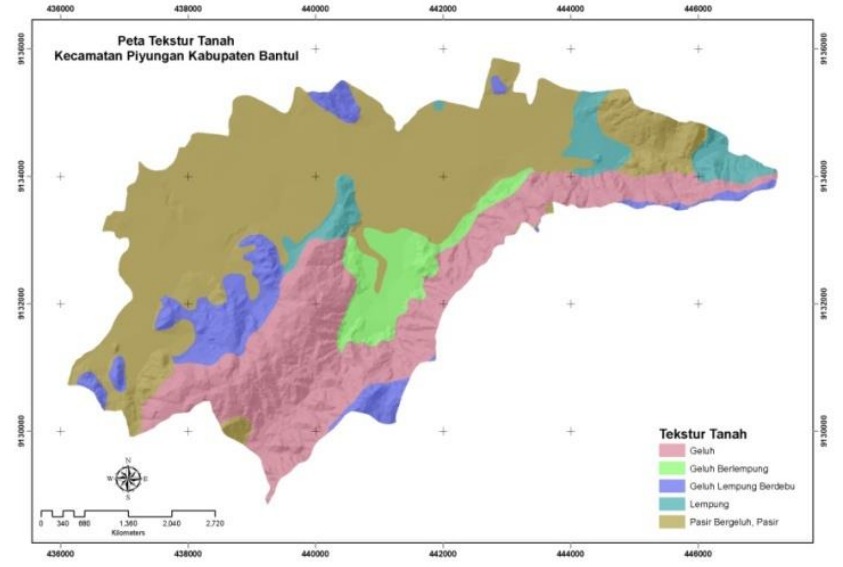

Gambar 4.5 Peta Tekstur Tanah Wilayah Kecamatan Piyungan

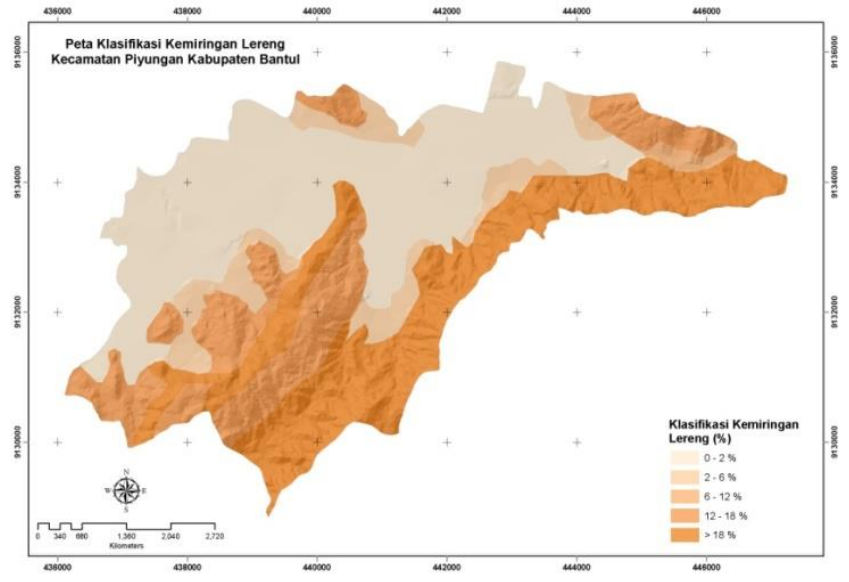

Gambar 4.6 Peta Kemiringan Lereng Wilayah Kecamatan Piyungan

Hasil pemetaan kerentanan airtanah dengan model DRASTIC menunjukkan bahwa Kecamatan Piyungan memiliki kerentanan airtanah dari tingkat tidak rentan sampai dengan kerentanan airtanah sangat tinggi. Wilayah yang tergolong tidak rentan adalah wilayah bukan akuifer yang menempati perbukitan dengan batuan vulkanik tersier yang kedap air. Kerentanan sangat tinggi terdapat pada dataran aluvial Merapi bagian Timur Laut Kecamatan Piyungan yang memiliki kedalaman airtanah 3-9 meter, media akuifer berupa pasir, kemiringan lereng 0\%-2\%, tekstur tanah pasir, media akuifer tidak jenuh dan media akuifer utama berupa pasir dan kerikil serta memiliki curah hujan tinggi $(1500-1800 \mathrm{~mm} / \mathrm{tahun})$ (lihat Gambar 4.7).

Perlakuan tumpangsusun (overlay) peta kerentanan airtanah dengan peta penggunaan lahan dapat menghasilkan informasi risiko pencemaran airtanah sebagai peta bahaya pencemaran. Hasil analisis menunjukkan bahwa risiko pencemaran airtanah di Kecamatan Piyungan ialah mulai dari tingkat risiko sangat rendah sampai dengan risiko tinggi. Wilayah yang memilik risiko tinggi terdapat pada dataran aluvial Merapi yang terletak di bagian Timur Laut. (lihat Gambar 4.8). Wilayah ini memiliki risiko yang tinggi karena memiliki kerentanan yang tinggi dan memiliki permukiman yang padat. Hal ini dapat dimungkinkan karena lokasi tersebut merupakan simpul jalur transportasi yang menghubungkan Yogyakarta, Bantul, Wonosari, serta Solo, yang kemudian menjadi pusat ekonomi Kecamatan Piyungan. 


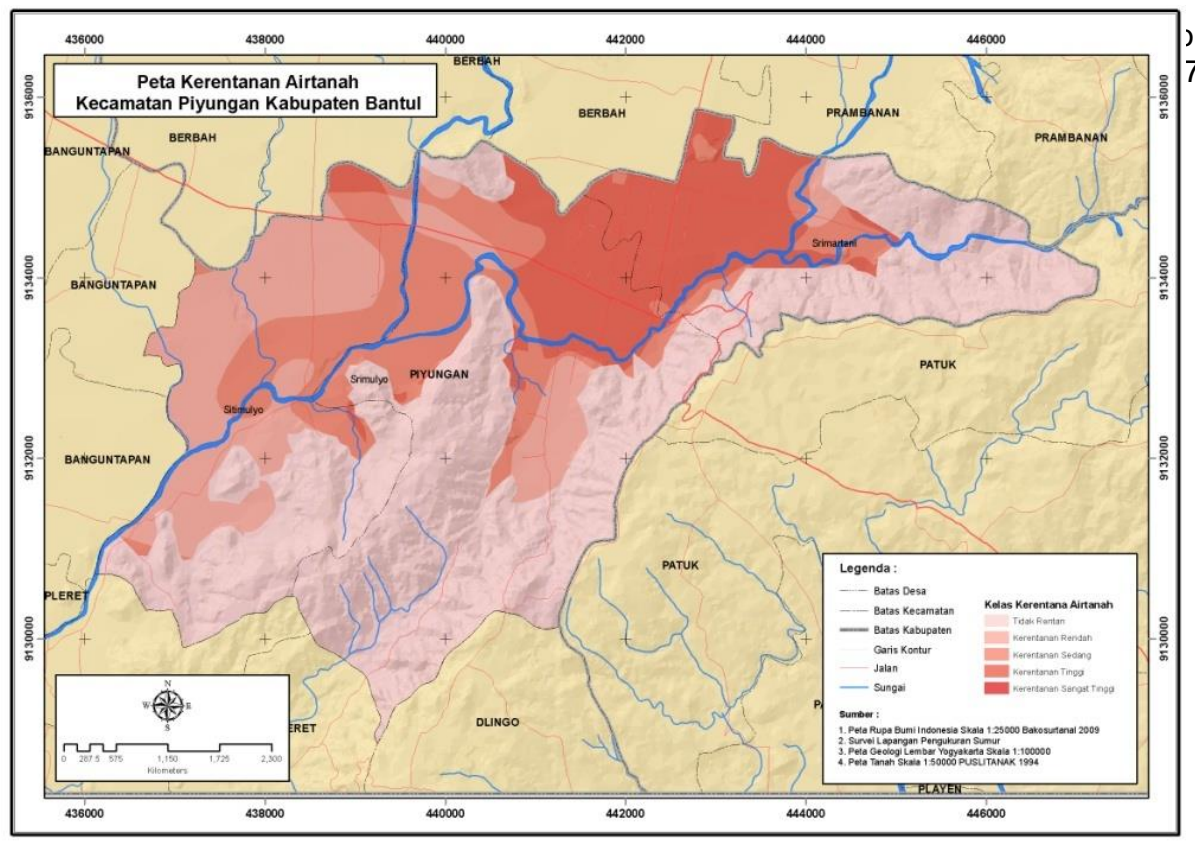

Gambar 4.7 Peta Kerentanan Airtanah Kecamatan Piyungan

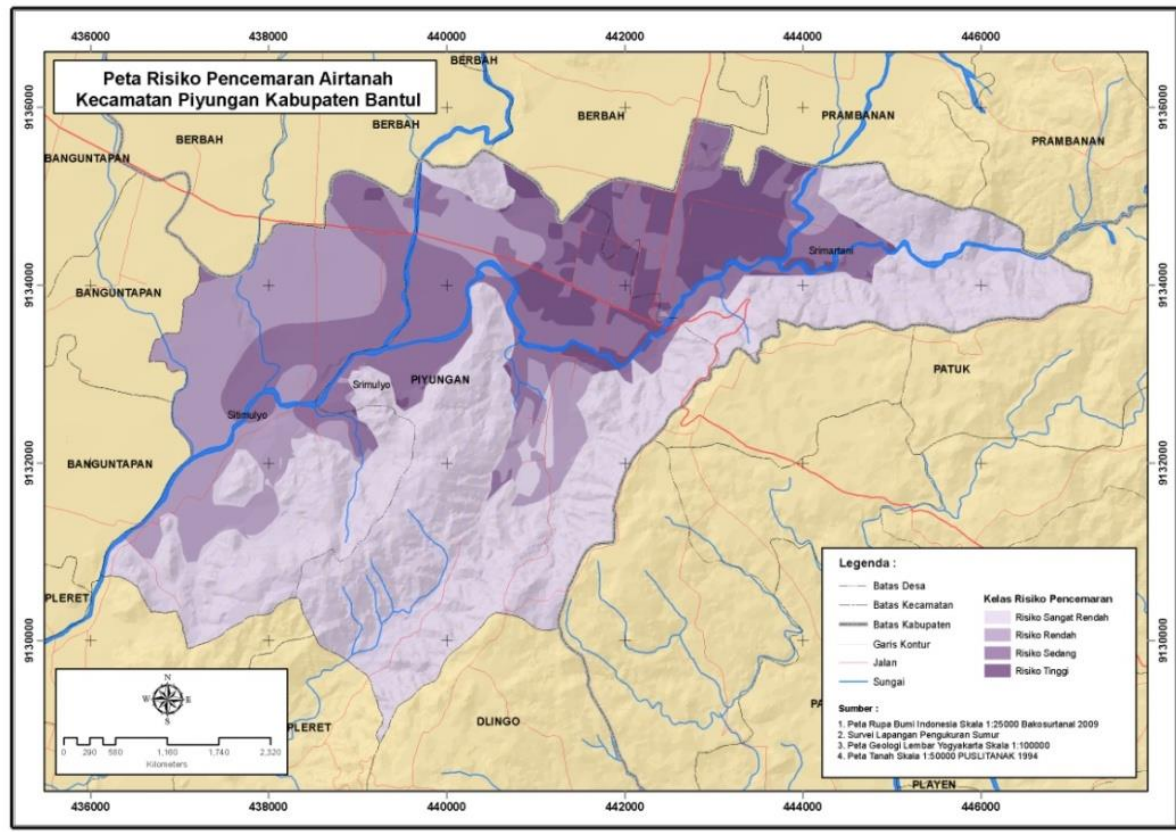

Gambar 4.8 Peta Risiko Pencemaran Airtanah Kecamatan Piyungan

\section{KESIMPULAN}

1. Kerentanan airtanah di Kecamatan Piyungan terdiri atas tingkat tidak rentan sampai dengan kerentanan airtanah sangat tinggi. Wilayah yang tergolong tidak rentan merupakan wilayah bukan akuifer yang menempati perbukitan, sedangkan kerentanan sangat tinggi terdapat pada dataran aluvial Merapi bagian Timur Laut Kecamatan Piyungan.

2. Risiko pencemaran airtanah di Kecamatan Piyungan terdiri atas tingkat risiko sangat rendah sampai dengan risiko tinggi, di mana risiko tinggi terdapat pada dataran aluvial Merapi yang terletak di bagian Timur Laut. 


\section{DAFTAR PUSTAKA}

Comans, R.N.J, van der Weijden, C.H., dan Vried, S.P.,. "Geochemical Studies in Drainage Basin of the Rio Vouga, Portugal. IV. Impact of Landuse on the Hydrogeochemistry of Natural Waters in the Vouzela Region”, Jurnal Enviromental Geology Water Science, 9(2), hal 119-129 (1987).

Sudarmadji., "Perembetan Pencemaran dalam Airtanah Pada Akuifer Tak Tertekan di Daerah Lereng Gunungapi Merapi”. Laporan Penelitian. Yogyakarta : PAU Ilmu Teknik UGM (1990).

Vörösmarty, C. J., P. Green, J. Salisbury and R. B. Lammers., "Global Water Resources: Vulnerability from Climate Change and Population Growth”, Science, 289, 284 - 28 (2000).

Widyastuti, M; Notosiswoyo, S; dan Anggayana, K., "Pengembangan Metode DRASTIC untuk Prediksi Kerentanan Airtanah Bebas Terhadap Pencemaran di Sleman", Majalah Geografi Indonesia, 20(1). 32-51 (2006).

\section{UCAPAN TERIMA KASIH}

Penulis mengucapkan terimakasih kepada Biro Perencanaan dan Kerjasama Luar Negeri (BPKLN) Kementrian Pendidikan Nasional Republik Indonesia, yang telah memberikan BEASISWA UNGGULAN pada penulis kedua dan ketiga pada Magister Perencanaan Pengelolaan Pesisir dan Daerah Aliran Sungai, Fakultas Geografi, UGM. Semoga program ini dapat terus dilaksanakan sehingga tercipta sumberdaya manusia yang maju, sejahtera dan mandiri. 